NBER WORKING PAPER SERIES

\author{
CADILLAC CONTRACTS AND UP-FRONT \\ PAYMENTS: EFFICIENT INVESTMENT \\ UNDER EXPECTATION DAMAGES
}

Aaron S. Edlin

Working Paper No. 4915

\author{
NATIONAL BUREAU OF ECONOMIC RESEARCH \\ 1050 Massachusetts Avenue \\ Cambridge, MA 02138 \\ November 1994
}

This paper expands upon Edlin [1993, section 3.3]. I thank Tai-Yeong Chung for his extensive comments as well as Eric Emch, Mario Epelbaum, Benjamin Hermalin, Stefan Reichelstein, William Rogerson, Joseph Stiglitz, Robert Wilson and the participants of the 1994 American Law and Economics Association Meetings at Stanford for helpful conversations or comments. The paper was presented at the 1994 meetings of the American Law and Economics Association, and at Northwestern University's 1994 Micro Week Conference. This paper is part of NBER's research program in Law and Economics. Any opinions expressed are those of the author and not those of the National Bureau of Economic Research.

(C) 1994 by Aaron S. Edlin. All rights reserved. Short sections of text, not to exceed two paragraphs, may be quoted without explicit permission provided that full credit, including (C) notice, is given to the source. 
NBER Working Paper \#4915

November 1994

\title{
CADILLAC CONTRACTS AND UP-FRONT \\ PAYMENTS: EFFICIENT INVESTMENT \\ UNDER EXPECTATION DAMAGES
}

\begin{abstract}
This paper shows that up-front payments can play a crucial role in providing efficient investment incentives when contracts are incomplete. They can eliminate the overinvestment effect identified by Rogerson [1984] and Shavell [1980] when courts use an expectation damage remedy. This method extends to complex contracting situations if parties combine up-front payments with what we call "Cadillac" contracts (contracts for a very high quality or quantity). This combination provides efficient investment incentives in complex contracting problems when an expectation damage remedy is accompanied by a broad duty to mitigate damages. This indicates that an expectation remedy is well-suited to multidimensional, but one-sided, investment problems, in contrast to specific performance, which Edlin and Reichelstein [1993] showed is well-suited to two-sided, but unidimensional, investment problems.
\end{abstract}

Aaron S. Edlin

Department of Economics

University of California at Berkeley

Berkeley, CA 94720

and NBER 


\section{Introduction}

Lip-front payments are common enough. One may wonder, though. why one party to a contract sometimes pays the other before the other perlorms? This essay identifies a new purpose for this practice: Up-front payments, combined with what we call "Cadillac" contracts, can provide a simple solution to the incomplete contracting problem, a solution that incorporates the traditional remedy of expectation damages with a broad duty to mitigate damages. This solution is remarkably robust, working not only in the simple contractual settings of Rogerson [1984] and Shavell [1980], but in settings where the investment decisions are complex, though made by only one party.

Up-front payments are often associated with special orders, custom goods, or other contracts involving specific investments. This is probably no accident. Whenever investments are relationship-specific, the investor risks a tholdup-i.e. he risks losing the returns to his investments in negotiations after the investments are sunk. Adequate protection must somehow be provided, and Williamson [1983] has argued that if courts are an impractical option, then up-front payments serve to protect investınent returns against the holdup problem. ${ }^{1,2}$

We ask here whether such payments are useful in the polar case when courts are effective. The initial response of those familiar with law and economics might be "no" at least for the extreme cạse where courts can costlessly enforce contracts. After all. Rogerson [1984] and Shavell [1980] showed that enforceable fixed-price contracts not only protect investment returns, but can overprotect them and cause overinvestment.

\footnotetext{
'Wiltiamson [1983] calls such up-front payments "hostages," and develops a model of "private ordering in which a hostage is paid to the investor-eeller up front. Tbis payment serves to bind the buyer, substituting for an enforceable contract.

${ }^{2}$ Eigh legal fees can make court an impractical option; alternatively, courts can be ineffective if one party is unreliable and may flee from the court's juriadiction, or become judgment-proof from insolvency.
} 
If such contracts by themselves can overprotect investment, then why add an up-front payment?

This paper argues that up-front payments can play a richer role. They are important even in models where courts are costless and there is no fear of a judgment-proof defendant. They control which party chooses to breach the contract, thereby elinunating the Rogerson-Shavell overinvestment problem and providing efficient breach and investment incentives under a breach remedy of expectation daniages. ${ }^{3}$

Consider, for instance, the not-so-fictional story of an econonics department near Chicago. The department's building is undergoing substantial remodeling. remodeling that will definitely be completed in a year, perhaps even earlier. In the meantime, the department rents space in a commercial district on a 1-year lease. Although the landlord sets the rent high, he provides an up-front payment as an inducement to rellt the space: the first two months are free. Given the high rent, the landlord has no desire to terminate the tenancy (after the first $t$ wo months) since no one is offering higher rent. However, the department may desire to breach the contract and move out of the office space, if the remodeling nears completion before the lease terminates. In fact, the department will move out at the very time moving is efficient, assuming that it must pay the landlord damages calculated to compensate him for the breach (expectation damages). Moreover, the department will make efficient (multifaceted) ex-ante investment decisions. For instance, it will invest optimally in hastening the remodeling, and will also "settle into" the downtown building to just the right extent (making appropriate expenditures to decorate, move books, and buy new business cards and stationery; expenditures that take

\footnotetext{
${ }^{3}$ The reader familiar with Shavell [1880, p. 472] may be skeptical of this claim since his fourth conclusion is that "There does not exist a damage measure which leads to Pareto efficient decisions concerning both breach and reliance independent of the type of contractual situation." Moreover, Shavell [1980, p. 477] does not neglect the possibility of up-front payments, and jndeed assumes, "without loss of generality that the contract price $k$ is paid when the contract is made." However. Shavell is only considering up-front payments made by the investor to the non-investor instead of the other way around. His conclusion arises from this restriction.
} 
into account the likely lengths of stay).

The combination of the expectation damage remedy, the up-front payment, and the high rent is critical to the efficiency of this contract. The up-front payment induces the department to accept the high rent. The high rent, in turn, ensures that the alternativerental value of the office space stays below the rent. Otherwise, the department might not unilaterally move even though moving were efficient: since the department has the right to stay under the lease, the landlord would then have to bribe the department to move. The more "settled" it is, the larger the bribe would generally be: this means the department would have a (bribe-seeking) incentive to "overrely" on the lease: i.e., to overinvest in the specific investment of settling in. The overinvestment problem would turn out to worsen if the landlord could unilaterally breach, terminating the tenancy and paying the tenant expectation damages.

Such an overinvestment (overreliance) problem from expectation damages has become a textbook result in law and economics. Polinsky $[1989,3 \pi]$, for example. writes:

The espectation remedy generally leads to too much reliance because it gites the relying party the value that would have been created by the reliance in'estment if the contract had been performed.

Recent work indicates that the overinvestment problem is not so general as was thought when Polinsky wrote this passage. Rogerson [1984] and Shavell (1980] studied indivisible trade-trade either bappened or it didn't. In contrast, when the quantity the parties contract to trade is a continuous variable as in the lease example, Edlin and Reichelstein [1993] have now shown that simple fixed-price contracts can induce an efficient level of investment for one party under an expectation damage remedy. (Under specific performance, also Aghion, Dewatripont, and Rey [199t] and Chung [1991].) However. in the Rogerson-Shavell discrete-trade context, the balancing approach of Edlin 
and Reichelstein [1993] requires random contracts. ${ }^{4}$ Moreover, these approaches do not create appropriate incentives when the investment problem is multifaceted, as when the economics department above needs to decide its expenditures to speed the remodeling and also to settle into the downtown offices.

- This paper begins by returning to the Rogerson-Shavell context and showing that up-front payments to the investor provide efficient investment incentives under an expectation damage remedy without random contracts. This result furthers the argument that standard legal remedies do not necessarily cause overinvestment: the conventional wisdom embodied in the Polinsky quotation stems from the particular contracts Rogerson and Shavell considered. Our efficiency results remove the impetus to restrict the expectation damage remedy, as proposed by Cooter and Eisenberg .1985. p. 1467]; in fact, unrestricted expectation damages is a better "problem-solving" default rule than specific performance when only one party invests, (See Schwartz 199:3] for a helpfu] taxonomy of default rules.)

The intuition behind combining up-front payments and expectation damages is simple. The party that makes a sufficiently large up-front payment will not want to breach. since finishing performance requires only a commensurately small subsequent payment. ${ }^{\circ}$ Therefore, the other party will commit any breach. Controlling who breaches is critical under an expectation remedy, because the breacher gets the residual left after paying the victim compensatory damages. If the breacher is also the investor he will invest

\footnotetext{
'Hermalin and Katz [1993] develop a non-random solution for the discrete context; their fill-in-theprice contract is elegant, but is somewhat more complex than a fixed-price contract and requires that renegotiation be ruled out in the "symmetric information" cases considered here. (For general abstract mechanisms see Rogerson [1992]; for the use of liquidated damages see MacLeod and Malconson [1993] or Spier and Whinston [1994].)

${ }^{8}$ Cooter and Eisenberg [1985] argue that overreliance will not occur if expeciation damages prolect only the expectancy conditional upon efficient (or reasonable) investment. Spier and Whinston (1994] make the same argument.

'Implicit in this comment is the assumption that the breaching party cannot sue. This assumption is central and the paper will provide examples where it holds and where it doen't. Where it doesn't. policy conclugions follow.
} 
efficiently, maximizing this residual.

In Rogerson [1984] and Shavell's [1980] models, breach is committed by the party with the uncertain valuation of trade. If the breacher is not the investor, overinvestment results for the reason Polinsky described. ${ }^{7}$ In contrast, when the investor breaches, he invests efficiently, just as in the "second case" in Shavell $[1980,484-87]$, where the investor has the uncertain valuation and so is the party to breach. Section 2 simply observes that upfront payments allow the parties to control who breaches, so that the overinvestment effect from expectation damages is not mandated by the potentially exogenous arrangement of who must invest and who experiences uncertainty. The parties control their fate, and can avoid overinvestment by choosing an appropriate contract. ${ }^{8}$

Section 3 explains that the court does not have to observe damages for the approach in Section 2 to provide efficient investment incentives; the court need only make an unbiased damage judgment. Section 4 shows that this approach works in quite general settings where both parties' valuations are uncertain, and where one party makes multidimensional clioices about investment and trade. Allocating all "decision rights" both ex ante and ex post to one party is important, and to do this, we argue that the law (or perhaps the parties) should incorporate a broad duty to mitigate damages, a duty that includes accepting non-conforming performance. When the investor cannot be givell a decision right over production, a good substitute is for the contract to be "divisible," which allows the investor to breach one part of the contract without discharging the other party's duty to perform other parts of the contract. It is also inportant to the approach we outline to avoid situations with holdups where both parties must come to an agreement in order to trade efficiently. The parties may do so by signing a "Cadil-

\footnotetext{
'See Shavell's [1880, pp. 473-83] first case and also Rogerson [1984].

-Contrast this viewpoint with Shavell [1980, 473], who did not consider up-front payments being made to the investor. and who therefore described the situation in his "first case" as follows: "Notice here that the party who chooses reliance does not face uncertainty in a direet way and that the other party does. This means that the party who decides about reliance is not the one who decides about breach."
} 
lac ${ }^{n}$ contract-a contract to trade as high a quantity and quality as they are likely to want. Such a contract ensures that all adjustments of trade are "downward," and can be achieved with unilateral breach. Hence, Cadillac contracts and either divisibility or a broad duty to mitigate damages combine to extend the results in Section 2 to quite general contexts.

It should not be too surprising that efficient contracts exist, even in the general contexts of in Section 4. After all, the first-best should be attainable if one party is risk-neutral and can feasibly make all decisions. Compare the situation to a standard principal-agent framework where the solution would be to have the agent buy the firm. The solution presented here is interesting for at least three reasons. First it is historical: it shows that earlier overinvestment results stemmed from restrictions on the form of contract. Second, it illustrates how fixed-price contracts can interact with legal doctrines such as expectation damages, a broad duty to mitigate damages, and contractual divisibility, to effectively give all decision rights and the residual to one party. This suggests a variety of guiding principles for parties writing contracts or for courts constructing problem-solving default rules. Third, it incorporates up-front payments made to the party that undertakes investment, a common phenomenon that differs from the investor buying out the other party. (Our agent, instead of buying out the firm, is paid a significant up-(ront sum in return for promising to deliver the maximum output.)

The paper has four remaining sections. Section 2 explains the importance of up. front payments in the disçrete context of Rogerson and Shavell. Section 3 relaxes the informational requirements of the court. Section 4 generalizes the contract solution to a context where investment and deployment of assets are multidimensional decisions, and where both parties place unknown value upon trade. Section 5 discusses implications. 


\section{Discrete Trade Revisited}

\subsection{The model}

This section lays out a model of discrete trade like those in Rogerson [1984] and Shavell [1980]. A risk-neutral buyer and seller contract to trade a good, and one party, in our case the seller, must invest $S \in[0, \bar{S}]$ before the other's trade valuation is known. If the good is produced ex post, the seller must later incur the variable cost $c(S) .^{9}$ If the good is not produced, the investment may be redeployed to earn an alternative use value, or salvage value, $\bar{a}(S)$, where $\bar{a}(0)=0$. The traded good has a randon value $v(\theta)$ to the buyer, where $\theta$ denotes the realized contingency. We assume that both parties observe the values $v$ and $c$ ex post. after the investment and contingency are determined. Production and trade are efficient ex post if and only if the value to the buyer is sufficiently high that

$$
v(\theta)-c(S) \geq \bar{a}(S)
$$

Otherwise it is better to sell the investment as salvage for $\bar{a}(S)$.

We assume some optimal in restment level or levels exist. Since both buyer and seller are risk-neutral, any first-best level of investment satisfies

$$
S^{*} \in \arg \max _{S \geq 0} \int \max [v(\theta)-c(S), \bar{a}(S)] d F-S
$$

where $F(\theta)$ is the cumulative distribution for contingencies $\theta$. The timing of events is summarized below.

\footnotetext{
'In Rogerson [1984] and Shavell [1980] the buyer invests and the seller has uncertain costs. This difference is unimportant here. However, when trade is not discrete, as in Section 4, it becomes important. Tbere we explicitly prenent a solution method involving a broad duty to mitigate damages. On the other hand, if the buyer invests, a parallel analyois would involve the contract being "divisible," a concept we elaborate later.
} 


\section{Time Line}

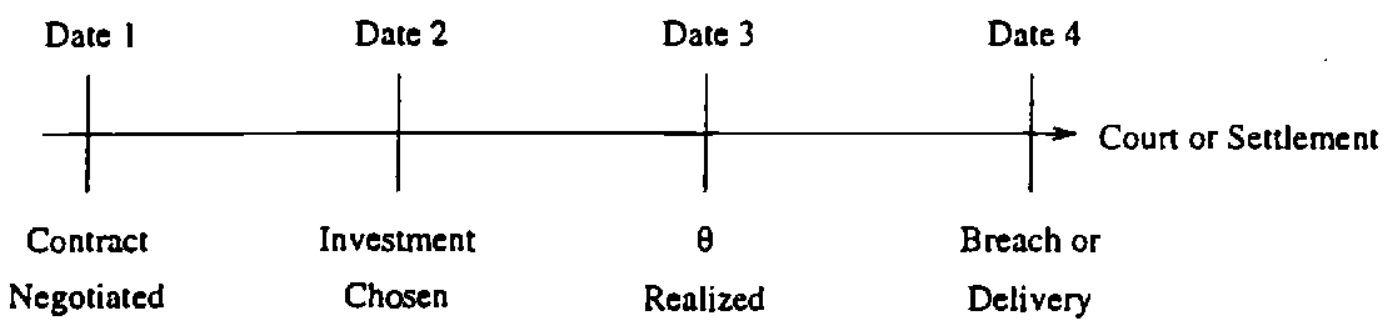

Figure 1:

\subsection{Efficient investment from up-front payments}

We show below that when an up-front payment is possible, the parties can sign a fixedprice contract that provides optimal investment incentives. The parties should sign such a contract since it maximizes joint surplus, and this surplus can be divided arbitrarily with the up-front payment.

We begin by defining up-front payments.

Definition 1. An up-front payment is anything valuable delivered at the time a contract is signed (other than the promise of payment for the goods). It might represent money paid, another profitable trade, or the signing of a separate profitable agreement.

We consider a fixed-price contract to trade the good at a price $p$ to be paid at the time of trade. The buyer also pays the seller an amount $T$ up front, which may be viewed as compensation for the seller's investment. This up-front payment plays a critical role in creating efficient investment incentives.

We assume that if either the seller or the buyer breaches the contract, the other party may choose to sue to get an expectation damage remedy imposed. In contrast, the breaching party cannot sue on a "breach of contract" theory since the other party has 
breached no contractual duty. We also assume that the breaching party cannot sue in what is called "quasi-contract," and that the court will find no other reason to assist the breaching party. ${ }^{10}$ This latter assumption does not accurately reflect the legal system in some jurisdictions and cases. For instance, the doctrine that a "willful" contract breacher cannot sue is common but not universal. ${ }^{11}$ Where the assumption does not presently apply, our analysis will generate a legal policy recommendation as well as a contracting recommendation. The policy recommendation is that courts should become increasingly skeptical of such suits in quasi-contract; but until they do, the contracting prescription is that parties pay the up-front payment in a separate contract with separate consideration. These prescriptions eliminate a race to breach, ${ }^{12}$ and allow the parties to neatly overcome the overinvestment problem by controlling who breaches.

To be concrete about the sort of unjust enrichment suit that will prevent the parties from solving their contracting problem, consider the lease example in the introduction. Suppose that while the economics faculty is attending the Winter AEA meetings, the landlord removes their belongings and re-rents their offices. They can sue for breach of contract to recover any damages they suffer, but they may suffer no damages: They

\footnotetext{
${ }^{10}$ The possibility of suing "in quantum meruit," one type of "quasi-contractual" suit, is a longestablished way to recover benefits conferred on another who the court deems would otherwise be unjustly enriched. Even where there is a contract, and one party has clearly breached the contract, courts have olen allowed that party to recover the value of benefits be conferred upon the victim of the breach. (See, e.g., Britton v. Turner [1834], where the plaintiff breached a twelve-month labor contract by working only nine and one-half months, but was allowed to recover nine and one-half month's wages.) However, courts sometimes refuse to allow such recoveries. See Berke $\forall$ Co. v. Grifin, Inc. $(1976,764]$ where the court notes that, "generally quantum meruit recovery will not be awarded where the conduct has been 'wilful' [sic]."

"See the comment later regarding Berke \& Co. v. Griffin, Inc. (1976]. Some commentatorg argue that even a willful breacher should be accorded relief. See Nordstrom and Woodland [1959, 211-14].

${ }^{12}$ If quantum meruit recovery is allowed for the breacher, extreme perversities may result. Suppose that unjust enrichment means receiving more then one's expectancy resulting from another's breach, and suppose further that a contract breacher can always sue to prevent unjust enrichment. Then both buyer and seller will be in ace to breach when trade is inefficient. Each will attempt to make announcements of his refusal to perform in advance of the other's announcements. More peculiar still, each will assert in court that the announcement of the other did not amount to an anticipatory repudiation or breach! These Alice-in-Wonderland phenomena occur if the breacher can always "pin" the other party to his expectsncy by suing for disgorgement of any surplus from not trading when that is efficient.
} 
may find other accommodations for less rent and not be much inconvenienced. Would the landlord, then, be able to sue them to recover the rent for the two free months they enjoyed at the beginning of their lease, or for their rental savings from their involuntary relocation? Were they "unjustly enriched"? In this paper, we assume the answer is no: The landlord who breached has no cause of action. This assumption is probably realistic in this example, however, in other examples where the structure of the contract and flavor of the breach differs, some jurisdictions will allow the breacher to sue. This paper provides reasons not to. We will return to these issues later.

Since we follow Rogerson (1984) and Shavell [1980) in ignoring litigation costs, a breach victim will sue whenever damages are positive. Although abstracting from litigation cost necessarily limits the descriptive power of this paper, it allows us to further develop the influential benchmark case they considered. For now, we assume that the court has sufficient information to properly calculate damages. As Shavell [1980] emphasizes, this requires the court to observe the value $v(\theta)$, but not the state $\theta$ nor the functional relationship $v(\cdot)$. Section 3 of this paper considers imperfectly informed courts that cant $t$ observe even $v$.

Damages will be calculated using the expectation formula; this fornula compensates for economic damages, and is defined as follows:

Definition 2. Expectation damages are the amount that makes the victim of a breach exactly as well off as she would have been if the other party had performed.

Expectation damages give the victim what lawyers call her "expectancy." Accordingly, if the seller breaches, he will have to pay the buyer

$$
\max [0, v(\theta)-p]
$$

If the buyer's damages $v(\theta)-p$ are positive, the buyer gets the same payoff as performance. She can bring an action to recover $v(\theta)-p$, or equivalently, since they anticipate the 
result, the parties may simply settle out of court. If $v(0)-p$ were negative, the buyer would not sue, so the seller pays 0 . If the buyer breaches, she must likewise pay the seller

$$
\max [0, p-c(S)-\bar{a}(S)],
$$

assuming that the buyer notifies the seller of the breach before he incurs the variable costs $c(S)$. Again the "max" takes into account the fact that no one forces the seller to sue. The seller's expectancy is $p-c(S)$, but $\bar{a}(S)$ is deducted because the seller is obligated to "mitigate" his damages by selling the investment at its salvage value. ${ }^{13,14}$ Although the duty to mitigate damages can induce efficient actions ex post, this feature is inconsequential in a symmetric information context where renegotiation is possible. The duty to mitigate damages is nonetheless quite important for efficient investment incentives, and Section 4 explains that in a more general setting, the duty to mitigate damages should be broader than the law often recognizes.

When contractual quantity is not an available instrument, the key to inducing effcient investment is to set the price low so that the seller-investor commits any breach. (Compare with Edlin and Reichelstein [1993], where quantity is used as an instrument.) Proposition 1. Let $p \equiv \inf v(\theta)$. Then the seller invests and breaches efficiently. However, unless trade is always efficient, the seller must be paid an up-front payment, or he will not agree to such a low price.

\footnotetext{
${ }^{13}$ If the buyer wants to breach, she should announce her intention early, repudiating the contract. Otherwise ber damage payment might increase by $c(S)$ (if the seller produced) or even $c(S)+\bar{a}(S)$ (if the seller produced and lost his opportunity to salvage his investment).

${ }^{14}$ The duty to mitigate generally bars a plaintiff from recovering costs incurred after cancellation of the contract. A canonical example is found in Rockingham County v. Luten Bridge Co. (1929), where Luten Bridge Co. continued building a bridge after notice of cancellation was given by Rockingham County. Rockingham successfully asgued that it owed Luten only the "damages which the company would have oustained, if it had abandoned construction at that time." Note, bowever, that some expenses incurred after cancellation are recoverable. For lnstance, advertioing expenses are generally recoverable when they might reasonably increase salvage value; in a typical view, such expenses are recoverable even "where the result is an aggravation of the damages rather than a mitigation," if "expenses are the result of a prudent attempt to minimize dameges." (Mr. Eddie, Inc. o. Ginoberg (1968), a breach of contract case, where a wrongfully dismissed employee under a three-year employment contract spent $\$ 1,340$ in an unsuccessful job search.)
} 
Proof: Suppose the buyer does not breach, but stands ready, willing, and able to buy. Then either the seller performs and the buyer pays $p$ and enjoys $v(\theta)$ from consuming the good, or the seller breaches and must pay $v(\theta)-p$ in damages. Either way, the buyer has payoff $v(\theta)-p$, which is non-negative since $p \equiv \inf v(\theta)$. Performance is therefore a weakly dominant strategy, since breach would yield the buyer at best 0 , and even less if the seller sued. (Recall that we assumed the buyer cannot breach and sue.)

If the seller breaches, he will be sued. His payoff will be the salvage value minus damages, i.e., $\bar{a}(S)-[v(\theta)-p]$. If the seller performs, he receives $p-c(S)$, so he breaches if and only if ${ }^{15}$

$$
\bar{a}(S)-v(\theta) \geq-c(S)
$$

This inequality matches inequality (1), so the parties trade if and only if trade is efficient ex post. Since expectation damages is a liability rule allowing unilateral breach, no renegotiation is necessary for efficient trade.

The seller's investment problem is to choose

$$
\hat{S} \in \arg \max \int \max [p-c(S), \bar{a}(S)-v(\theta)+p] d F-S
$$

This optimization differs from the social optimization given by (2) only by adding $p-v(\theta)$ in each contingency. Investment incentives are unaltered, so we have shown that choosing $p=\inf v(\theta)$ induces efficient investment and breach.

Nonetheless, the buyer must pay the seller an up-front payment to induce him to sign such a contract unless trade is always efficient. That is, consider a case where trade is sometimes inefficient: i.e., for some $\theta^{\prime}, v\left(\theta^{\prime}\right)-c\left(S^{*}\right)<\vec{a}\left(S^{*}\right)$. Since by construction $p \leq v\left(\theta^{\prime}\right)$, substitution yields $p-c\left(S^{*}\right)<\bar{a}\left(S^{*}\right)$. Without an up-front payment, the seller would be better off avoiding the contract, investing $S^{*}$ and selling it as scrap. ${ }^{16} \mathrm{D}$

\footnotetext{
${ }^{15}$ Ties where $v(\theta)=c(S)$ leave the seller indifferent.

${ }^{16}$ If the optimal investment $S^{*}$ is not unique, read $S^{*}$ as the seller's choice from among the optima.
} 
Thus, the seller invests efficiently if the buyer and seller agree to trade at the favorable price given in Proposition 1. However, the buyer must often pay the seller some up-front payment $T$ to convince him to sign the contract under these favorable terms. In fact, an up-front payment is necessary in cases where Rogerson-Shavell overinvestment occurs, i.e.. in cases where trade is sometimes inefficient. (Note that the up-front payment might not be necessary if costs were uncertain as well.)

A similar efficiency result holds if the buyer invests before the seller's costs are known.

Proposition 2. Suppose the buyer invests, and let the valuations be $v(S)$ and $c(\theta)$. Then if $p \equiv \sup c(\theta)$, the buyer invests and breaches efficiently.

Proof: The proof is left to the reader, since it is essentially the same as when the seller invests. $\square$

Our assumption that the contract breacher cannot sue may at times appear punitive to the breacher. For instance, if the buyer invests and the seller fails to deliver, the buyer keeps any up-front payment. Possibly, the buyer gets more than her expectancy out of the deal. We previously pointed out that in cases such as our lease example, it is realistic to think that the party who made the up-front payment has no recourse if she breaches. Another example is a record club whose membership consists of an initial enrollment purchase of twelve records for one cent together with the promise to pay a high price for some number of additional records at a later date. If the club later refused to sell the additional records (even at the high price), it is doubtful that the initial discounted sale would be voided, or that the buyer would owe additional money.

On the other hand, suppose a buyer puts down a deposit on a couch. only to cancel her purchase subsequently. If the deposit is unreasonably large "in light of the anticipated or 
actual harm caused by the breach, the difficulties of proof of loss, and the inconvenience or nonfeasibility of otherwise obtaining adequate remedy," a court may insist that some of it be returned under the Uniform Commercial Code Section 2-718. Yet, suppose the couch were custom-made and that the maker had to order special fabrics and foams with low resale value. In consideration of this specific investment, the customer makes what we call an up-Iront payment; or, perhaps she simply buys the materials Irom the maker, and a separate contract is written to build the couch, so that if the buyer cancels the construction (breaching), she should be entitled to no refund on her purchase of materials (or payment for investment). When the buyer is seen to be purchasing the investment in a separate deal, the up-front payment will not be refundable to a breaching buyer unless the investment were not made. If the up-front payment were made in a separatc agreement. the penalty doctrine might not apply across the agreements.

Again. we remind the reader that the above analysis is valuable even in those cases or jurisdictions where the breacher could sue. Then, the analysis provides a policy reason why a breacher should not be able to sue. Allowing an up-front payment to stant even when it appears punitive lends the parties considerable contracting power. Notice: though, that efficiency is not driven simply by allowing what in some cases is tantamount to high stipulated damages; rather, efficiency results from the combination of these "high damages" preventing one party from breaching, and the expectation remedy giving the other party appropriate breach and investment incentives.

\subsection{No up-front payments: Overinvestment}

For the sake of contrast, we show below that if up-front payments are impossible (say; because of liquidity constraints), then the Rogerson-Shavell overinvestment problem returns. As the introduction discussed, Shavell [1980] considers up-front payments but only payments made to the non-investor. Without an up-front payment made to the 
investor-selier, he will not agree to the low price that drives Proposition 1; instead, he will demand a price $p$ such that

$$
p-c(\tilde{S}) \geq \bar{a}(\tilde{S}),
$$

where $\tilde{S}$ is whatever investment the seller chooses given the contract. (If the inequality were violated, the seller would always lose money.) With such a "high" price, as we shall see, the seller always performs and the buyer becomes the potential breacher.

In order to derive the Rogerson-Shavell overinvestment effect, we must impose additional structure on the model:

(A1) $-c^{\prime}(S)-\bar{a}^{\prime}(S)>0$;

(A2) $S^{*}$ as defined by (2) is unique and $S^{*} \in(0, \bar{S})$;

$$
\int_{\theta: v(\theta)-c\left(S^{*}\right)<\bar{a}\left(S^{*}\right)} d F>0 .
$$

Assumption (Al, states that marginal investment lowers production costs by more than it increases salvage value." Assumption (A2) is self-explanatory and (A3) states that when $S=S^{*}$, salvage is efficient with positive probability. These assumptions about functional form and the uniqueness of $S^{*}$ were unnecessary to prove Proposition 1 , but we need them here to replicate the traditional overinvestment result.

Proposition 3. Assume (A1), (A2), and (A3). Then, without an up-front payment to the investor-seller, he overinvests. (This proposition is essentially like those of Shavell [1980] and Rogerson (1984].)

Proof: As argued above, when up-front payments are impossible. the seller will only agree to a price $p$ such that $p-c(S) \geq \bar{a}(S)$, when evaluated at the investment level

\footnotetext{
${ }^{17}$ This assumption corresponds to assumption 3 in Rogerson [1984], except that he wrote it as a weak inequality, and proved weak overinvestment.
} 
he intends to take. Consequently if the buyer stands ready to perform, the seller also performs and receives $p-c(S)$. (The seller's other alternative is to salvage, which yields $\bar{a}(S)$ if the buyer doesn't sue, and even less if the buyer sues.) If the buyer breaches, the seller will sue to recover

$$
\text { Damages }=p-c(S)-\bar{a}(S) .
$$

After salvaging his investment for $\bar{a}(S)$, his net payoft is his expectancy $p-c(S)$, just as when the buyer performs. The seller's investment problem is therefore

$$
\max _{S} p-c(S)-S
$$

To prove that the seller overinvests. compare this problem to the joint surplus maximization problem (2) and

(A) observe that (A3) guarantees that when $S=S^{*}$, salvage is efficient with positive probability:

(B) subtract the social planner"s objective function from the seller's and observe that the difference is strictly increasing in $S$, because of observation (A) and assumption (A1): and

(C) apply Milgrom and Shannon's [1994] Monotone Selection Theorem, which implies that when comparing solutions to two (single-variable) optimization problems, if the first problem has an objective function with higher returns to increases in the control than the second, then maximizers for the first optimization problem (weakly) exceed those for the second.

The above observations show that the seller's chosen investment weakly exceeds the social optimum $S^{*}$. Moreover. observations A and B together imply that the seller strictly overinvests because his first-order necessary condition is not satisfied by $S^{*}$. (Recall that $S^{\bullet}$ is interior by assumption.) Intuitively, the seller is overcompensated for his incremental investment by the expectation damage remedy, because when trade 
is inefficient, he receives the full cost savings that incremental investment would yield during production, $-c^{\prime}(S)$, instead of the lesser "social return" from salvage, $\bar{a}^{\prime}(S)$.

Overinvestment results when up-front payments to the investor are impossible and the value of trade to the non-investor is the source of uncertainty. However, as we have seen, sufficiently large up-front payments to an investing seller combined with a commensurately low subsequent price ensure efficient investment. Since the buyer has already almost fully or even fully performed, she will not breach no matter what her value. This leaves the decision to breach in the hands of the investor. Under an expectation remedy, a combined breacher-investor gets the full residual surplus ex post, and so has the incentives ex ante to invest to maximize this surplus. This principle applies to far more general contexts than the Rogerson-Shavell model, as shown by the following two sections.

\section{Imperfectly Informed Courts}

This brief section demonstrates that the analysis of Section 2 is essentially unchanged when courts do not observe the true damages. What is critical is that the courts impose an unbiased measure of damages. This point, which is made in Edlin [1993], has proved sufficiently provocative to warrant further elaboration.

Suppose that when true damages are $D$, the court observes and imposes $\widehat{D}$, where

$$
\widehat{D}=D+\varepsilon,
$$

and $\varepsilon$ represents the court's error or misperception. Assume that the parties cannot anticipate the direction of the court's bias (i.e., the expected value of $\widehat{D}$ is $D$ ).

Since we are ignoring litigation costs, if the seller breaches, the risk-neutral buyer will still bring a case whenever the true damages $D$ are positive. Given the low trading price 
$p$, the buyer always brings the case. The seller's payoff from breach is

$$
\bar{a}(S)-\widehat{D}=\bar{a}(S)+p-v(\theta)-\varepsilon
$$

and from performance is

$$
p-c(S)
$$

The risk-neutral seller breaches whenever the expected payoff from breach exceeds that from performance. This leads to the same breach rule as when the court's decision is predictable. Moreover, the seller's expected payoff is the same as before, so the seller has the same investment incentives. Thus, the unpredictability of court outcomes does not alter the analysis as long as the court imposes an unbiased judgement $\widehat{D}$ of damages, which establishes the following proposition:

Proposition 4. Proposition 1 holds even if the court does not observe true damages, as long as the court (observes some informative signal and) enforces an unbiased estimate of damages.

Proposition + partially addresses the criticisms of Schwartz [199:3, 406] about the information requirements of other mechanisms that might be used as problem-solving defaults. Of course, courts introduce a number of biases. Principal among these is the "certainty" requirement. Courts will not guess at damages if their information is woefully inadequate to the task. For instance, the new business rule "prohibits recovery of lost profits resulting from a breach of contract that has prevented the plaintiff from establishing a proposed new business. on the ground that profits in such cases are too speculative" (Fuller and Eisenberg [1990, p. 267]). In parallel fashion, in Freund v. Washington Square [1974], the Court of Appeals of New York found that Freund was entitled to only nominal damages for Washington Square's breach of a contract to publish bis book; sales were unpredictable, so only token damages could be awarded. Such a 
result biases damages downward. Therefore this model lends support to what Fuller and Eisenberg [1990, p. 267] label a "definite trend toward abrogating" the new business doctrine, and similarly to the flavor of the Official Comment in the Uniform Commercial Code to Section 1-106, which states that "Compensatory damages are often at best approximate: they have to be proved with whatever definiteness and accuracy the facts permit, but no more..." For a case in line with these trends, see Fera v. Village Plaza [1976], where the Alichigan Supreme Court upheld a $\$ 200,000$ jury verdict in favor of the plaintiffs who had signed a ten-year lease in order to open a "book and bottle" shop. (The plaintiffs were unable to take possession because the defendant subsequently leased the space to a third party.)

\section{General Settings and a Broad Duty to Mitigate}

The principles dereloped in Section 2.2 are quite general, as this section reveals. This generality gives the expectation remedy significant advantages over specific performance in one-sided investment problems. To realize these advantages, a broad duty to mitigate damages is a useful supplement to an expectation remedy when the seller invests. When the buyer invests. a divisible contract is correspondingly useful.

Consider a more general setting where the seller may supply many goods and services to the buyer, perhaps at different times and in different quantities or qualities. Let $q$ represent a list of the goods and services delivered, chosen from some set $Q$. Let $v(q, \theta)$ represent the value to the buyer of $q$ in contingency $\theta$.

(B1) Assume $Q$ has a maximal element $\bar{q}$ with non-negative value: i.e.,

$$
\exists \overline{\mathrm{q}} \text { s.t. } \forall \theta, \mathrm{q}, \quad v(\mathrm{q}, \theta) \leq v(\overline{\mathrm{q}}, \theta), \quad \text { and }, \quad v(\overline{\mathrm{q}}, \theta) \geq 0 \text {. }
$$

Definition 3. A Cadillac contract is a contract to trade a maximal element $\overrightarrow{\mathbf{q}}$. 
Cadillacs are large, luxurious cars, traditionally at the top of GM's line. Accordingly, a Cadillac contract is a top-of-the-line contract for a larger quantity or more quality than is generally efficient to trade. In fact, we have defined an extreme form of Cadillac contract involving the most valuable trade possible. If the Department of Defense orders 50 jet fighters of extraordinary capabilities, this may be a Cadillac contract. It will function as one if any renegotiations will be for jets with fewer capabilities and/or for fewer jets. Similarly, when a moving company promises to deliver all your belongings to your new residence intact, this is as valuable as their performance could be. (Those who have moved will know that many times their performance falls a touch below this high standard.)

A Cadillac contract generalizes an important feature of any non- random contract to trade in a discrete trade/no-trade context. It implies that any adjustments in trade are "downward." This feature was subtly implicit in the contracts in Section 2.

In this section, we assume the seller can buy $m$ assets, denoted by: $\mathbf{S} \in \mathbf{R}_{+}^{m}$, which may affect the cost of performing q. (Each of the $m$ assets may vary in scale or quality since each is associated with a real number.) The assets cost $I(\mathbf{S})$, where $I: \mathbf{R}_{+}^{m} \rightarrow \mathbf{R}$. Let the ex post cost of producing $\mathrm{q}$ be $c(\mathbf{S}, \mathrm{q}, \theta)$. The costs $c$ represent the most economical method of producing $\mathbf{q}$ with $\mathbf{S}$ given $\theta$. In some contingencies, this may involve selling as salvage some of the assets embodied in $\mathbf{S}$; in others, all of $\mathbf{S}$ may be fully used in production. It is worthwhile keeping in mind that the function $c$ is a reduced form, which may capture sophisticated deployment decisions. ${ }^{18}$

Suppose the parties have written a Cadillac contract to "trade" $\bar{q}$ with the entire

\footnotetext{
${ }^{10}$ As an example. let $A \in 2^{\{1 \ldots, m\}}$ represent the indices of the assets put to alternative use. $(A$ can be any subset of $\{1, \ldots, m\}$.) Then the assets in alternative use can be represented as $\sum_{i \in A} S_{i} e_{i}$, where $S_{i}$ is the ith element of $S$ and $e_{i}$ is the ith unit vector $(0, \ldots, 1, \ldots, 0)$. The value derived from the assets put to alternative use is $\bar{a}\left(\sum_{i \in A} S_{i} e_{i}, \theta\right)$. Suppose further that the costs of production of $q$ using the assets not in $A$ is $\bar{c}\left(\sum_{i(1, A} S_{i} e_{i}, q, \theta\right)$. Then. we would have$$
c(S, q, \theta) \equiv-\max _{A}\left[\bar{a}\left(\sum_{i \in A} S_{i} e_{i}, \theta\right)-\bar{c}\left(\sum_{i \notin A} S_{i} e_{i}, q, \theta\right)\right] \text {. }
$$ 
payment $T$ made up front, so that no payment is required when $\bar{q}$ is performed. ${ }^{18}$ Consider the situation after the investment $S$ is made and contingency $\theta$ realized. What will the seller supply? If the seller supplies $q \neq \bar{q}$, the buyer can accept or reject the tender. Regardless, the buyer will sue because by $(B 1), v(\bar{q} ; \theta) \geq v(\mathbf{q}, \theta)$, so the buyer suffers non-negative damages. ${ }^{20}$ If the buyer accepts $q$, her damages are

$$
D=v(\overline{\mathbf{q}}: \theta)-v(\mathbf{q}: \theta)
$$

If the buyer rejects $\mathbf{q}$, her damages depend upon the law's view of the duty to mitigate damages. If mitigation requires accepting partial or inferior performance, the buyer call recover at most $v(\bar{q}, \theta)-v(\mathbf{q}, \theta)$, which motivates the following definition.

Definition 4. Suppose a buyer has paid up front and been promised $\overrightarrow{\mathrm{q}}$. linder a broad duty to mitigate damages, if offered q. the buyer can collect only $v(\bar{q}, \theta)-v(\mathbf{q}, \theta)$ in damages.

Without a broad duty to mitigate, the breach victim may secure more than the benefit of her bargain by threatening to refuse $q$ unless the seller agrees to pay larger damages. This duty to mitigate is broader than often obtains. For instance, in Parker v. Twentieth Century-Fox [1970], the California Supreme Court held that Shirley MacLaine Parker did not need to accept Twentieth Century's offer to star in a western titled "Big Country, Big Man" to mitigate damages for Twentieth Century's breach of the contract in which she was to star in a musical titled "Bloomer Girl." Also, in the context of the sale of goods, under the Uniform Commercial Code Section 2-601, the buyer has the right to "reject the whole" if "the goods or the tender of delivery fail in any respect to conform

\footnotetext{
${ }^{19}$ It is possible to have some payments made at performance. but that requires a detailed discussion of the importance of a divisible contract.

${ }^{20}$ We assume that the non-conforming performance $q$ can be accepted without compromising the buyer's rights to her expectancy.
} 
to the contract. ${ }^{\text {n21 }}$ Moreover, under Section 2-711 a "rightful" rejection by the buyer leaves her with the same remedies as if the seller had not performed at all. Nonetheless, while a broad duty to mitigate may not presently obtain, the next proposition indicates it would have some advantages.

Proposition 5. A Cadillac contract to supply $\bar{q}$ for an up-front payment $T$ leads to efficient in vestment and breach when an expectation damage measure is applied and the buyer has a broad duty to mitigate damages.

Proof: Joint surplus is maximized by solving the following iterative program: Ex post, given assets $\mathbf{S}$, and the realized contingency $\theta$, choose $q$ to solve

$$
Z^{*}(\mathbf{S}, \theta) \equiv \max _{\mathbf{q} \in \mathbf{q}} v(\mathbf{q}, \theta)-c(\mathbf{S}, \mathbf{q}, \theta) .
$$

Ex ante, joint surplus is maximized by choosing $S$ to solve

$$
\max _{\mathbf{S}} \mathrm{E}\left[Z^{*}(\mathbf{S}, \theta)\right]-I(\mathbf{S})
$$

where $\mathrm{E}$ denotes the expectation operator.

Under a Cadillac contract, with payment $T$ made entirely up front, the seller solves a nearly identical problem. Suppose the seller delivers $q \neq \bar{q}$. Given the broad duty to mitigate damages, the buyer's rights will be limited to damages of $v(\overline{\mathbf{q}}, \theta)-v(\mathbf{q}, \theta)$ regardless of whether he rejects or accepts $q$. Since the contract is a Cadillac contract, $v(\bar{q}, \theta)-v(\mathbf{q}, \theta) \geq 0$, so the buyer will, in fact, demand, and if necessary sue for, payment of $v(\bar{q}, \theta)-v(\mathbf{q}, \theta)$. Therefore, given $\mathbf{S}$ and $\theta$, the seller chooses $\mathbf{q}$ ex post to solve

$$
W(\mathbf{S}, \theta)=\max _{\mathbf{q} \in q}-D(\mathbf{q}, \theta)-c(\mathbf{S}, \mathbf{q}, \theta),
$$

where damages $D(\mathrm{q}, \theta)=v(\overline{\mathrm{q}}, \theta)-v(\mathrm{q}, \theta)$.

\footnotetext{
"As other sections in the Uniform Conmercial Code make clear, these rights of rejection should not be read overly broadly, but they do apply to non-conformities that go to "the heart of the agreement."
} 
The seller's ex post objective function is the same as the joint surplus less $v(\bar{q}, \theta)$, so the seller's optimal choices of $q$ match those from surplus maximization. The seller's ex ante investment problem is to solve

$$
\max _{\mathbf{S}} \mathrm{E}[W(\mathbf{S}, \theta)]-I(\mathbf{S}) .
$$

Since $V(\mathrm{~S}, \theta) \equiv Z \cdot(\mathrm{S}, \theta)-v(\overline{\mathrm{q}}, \theta)$, the seller's ex ante choices of S similarly match those under joint surplus maximization, and the Cadillac contract to trade $\bar{q}$ for a payment made entirely up front leads to full first-best efficiency.

The expectation damage remedy allows us to find a contract $\bar{q}$ that leads to efficient choice of assets: efficient use of assets, and efficient performance or breach. Compare this with specific performance. Under a specific performance remedy: when the investment decision is a one-dimensional decision, fixed-price contracts can be efficient. These results require a continuous contractible variable $q$ and a number of assumptions about how investment affect: valuations (see Aghion, Dewatripont, and Rey [199t], Chung [1991], and Edlin and Reichelstein (1993\}). None of these assumptions are needed for the approach above. Moreover, even with those assumptions, the first-best can 't be implemented under specific performance when the investment decision is multi-dimensional (Edlin [1993] revealed, for instance, a bias toward investing in overspecialized assets instead of assets with higher values in alternative uses). No such biases exist under an expectation damage remed. with up-front payments and a Cadillac contract. Provided the parties can arrange for one party to make all the ex ante investment expenditures and decisions together with ex-post breach decisions, expectation damages is an ideal remedy.

The intuition behind Proposition 5 is as follows. A large up-front payment by the non-investing buyer to the investing seller ensures that the buyer performs the contract. A broad duty to mitigate damages, including accepting non-conforming performance. leaves the breach decision unilaterally in the hands of the investor. Otherwise some 
renegotiation would be necessary because the buyer could refuse a non-conforming tender; such renegotiation would typically involve splitting the returns to investment, which could distort investment incentives. The Cadillac contract eliminates contingencies where overperformance is efficient. Such contingencies also require bilateral negotiations and typically entail sharing the gains from extra performance, again distorting investment incentives. (The seller cannot capture all the gains from performing $q^{*}$ when $v\left(q^{*}, \theta\right)>$ $v(\bar{q}, \theta)$.

When the buyer invests, instead of the seller, the analysis proceeds sinilarly. For this "non-balancing" approach, we would then want the buyer to effectively diclate the level of performance and capture the residual created beyond the seller's expectancy. Two features are necessary. A Cadillac contract would ensure that the seller has a duty to deliver performance at least as valuable as is efficient. Second, if the buyer decides he wants to cancel (the inefficient) part of performance, this must not discharge the seller's remaining duty to perform the non-cancelled parts of the contract. This requires that the court construe the contract as "divisible" —essentially as a number of separate smaller contracts. Such a construction allows the buyer to cancel inefficient part $:$ of the contract and still have the seller deliver the efficient parts or pay compensatory damages. ${ }^{22}$ It thereby avoids negotiation and surplus-splitting, allowing the buyer-investor to capture all residual, just as the broad duty to mitigate allowed the seller-invessor to capture all residual in Proposition 5.

\footnotetext{
${ }^{22}$ In some cases where the buyer invests, a divisible contract is unnecessary. For inslance, in our lease example the economics departioent (the buyer) invests. The department has a property right to stay for the duration of the lease; moreover, it can move out early without needing any agreement from the landlord (though it would owe damages). Thus the law allocates decision rights over $q$ to the lessee, (at least when $q \leq \bar{q})$, which means no divisible contract is needed.
} 


\section{Implications}

The central result of this paper is that the expectation damage remedy need not lead to overinvestment in relationship-specific assets. In fact, even in the rery general context of Section 4. we found that all decisions were first-best. The conventional wisdom in the law and economics literature about distorted investment resulted from assumptions about which party breached, a fact noted by Shavell [1980] in the simple discrete-trade context of Section 2. Yet. even in that simple context, a major part of the puzzle was left out: If up-front payments to the investor are possible, the party who breaches is not determined exogenously by which party has uncertain valuations, as Shavell [19:0] assumed. Quite the contrary, when such up-front payments are possible, the parties themselves control who will want to breach in low-trade contingencies. When the non-investing party makes a sufficiently large up-front payment, she will want to carry out the contract even if her valuation proves unfavorable-any breach will be made by the investing part!: This arrangement provides efficient investment and breach incentives under the expectation damage fornula.

Thus when one party needs to make a specific investment, it is natural that the other should make some payment early. An up-front payment is desirable even when neither party will flee or become bankrupt and the legal system costlessly. enforces contracts. The payment determines who wants to breach, which is critical under an expectation damage remedy.

From this analysis we learn a number of lessons about policy. Potice first that we assumed that the breaching party could not successfully sue. This prevented the "race to breach ${ }^{-}$discussed in Section 2, allowing the parties to control who breached. This argues that courts should be skeptical of unjust enrichment claims, or at least honor contracts that give up the right to sue for unjust enrichment. Similarly, we provide another reason 
why courts should not invoke the penalty doctrine to return deposits.

Another lesson is that the courts should take a broader view of the duty to mitigateor at least stand ready to take a broad view if requested in the contract. Such a view of mitigation was critical to the efficiency of Cadillac contracts in Section 4 . Correspondingly, when the buyer is the investor, the critical issue becomes the divisibility of the contract.

A third lesson is that specific performance is not always the best remedy when specific investments are involved. Edlin and Reichelstein [1993] argued that specific performance is superior when both parties make investments (but where the investments were simplistic). Yet when the investment and breach decisions can all be allocated to one party, the expectation remedy is superior because multi-faceted investment can be efficient. Therefore, when parties neglect to specify a remedy, as they often do, expectation damages is a good default rule in one-sided investment problems. Its application implies that the ex ante incentives of the contract breacher were appropriate (at least the incentives arising from the given contingency). These first-best incentives may very well be gotten at the expense of incentives for the victim of breach (see Edlin and Reichelstein [1993]), but this will not matter if the victim does not make substantial reliance decisions.

The victim of breach may seek specific performance, because she may use the threat of forcing inefficient performance to increase her total payoff. The courts, however, should be loathe to grant it unless she can show some reliance or specific investment of her own. This proposal might be viewed as giving a new interpretation to the rule that specific performance is only granted when the "legal remedy" of damages are "inadequate." The inadequacy of damages is traditionally viewed as meaning that damages are difficult to measure, such as with unique chattel. Section 3 , however, showed that difficulty of measurement per se is not particularly important. The model indicates that the victim of breach should have to show that the remedy is "inadequate" because it does not provide 
parties in her position with appropriate incentives ex ante. Expectation damages would not provide appropriate incentives to the victim of breach (see Rogerson [1984], Shavell [1980], and Edlin and Reichelstein [1993]). When the breach victim also must invest, then, specific performance is better as it provides more balanced incentives (see Edlin and Reichelstein [1993]).

Finally, we should ponder the implications of Section 3, which explained that the accuracy of the expectation measure is not so important as its unbiasedness. This suggests that it is worthwhile to consider the efficacy of certain legal rules that tend to bias damages. One such rule is the rule that damages must be "certain".

Before closing, it is worth recalling some assumptions that warrant examination in future work. In particular, we have stuck to the Rogerson [1984] and Shavell [1980] assumption that courts are costless. This allows a better understanding of their work, hi"' relaxing the assumption would clearly be worthwhile to gain a more accurate descripu. theory. Relaxing the risk-neutrality assumption would also be a valuable exercise.

\section{References}

Aghion, P., M. Dewatripont, and P. Rey. 1994, "Renegotiation Design with Unverifiable Information." Econometrica 64, 257-82.

Aghion, P., and B. Hermalin, 1990. "Legal Restrictions on Private Contracts Can Enhance Efficiency." Joumal of Law, Economics, and Organization 6, 381-409.

Berke \& Co. v. Griffin, Inc. [1976], 116 N.H. 760.

Britton v. Turner [1834] 6 N.H. $\cdot 481,26$ Am.Dec. 713.

Chung, T.-Y, 1991. "Incomplete Contracts, Specific Investments, and Risk Sharing." Review of Economic Studies $58,1031-42$. Cooter, R., and M. A. Eisenberg. 1985. "Damages for Breach of Contract." California Law Review 73,
1432-89.

Edlin, A. S. 1993. "Specific Investments, Holdups, and Efficient Contract Remedies." Chapter 1 of Aspects of the Efficient Recovery of Fired Costs: $A$ Collection of Essays. Ph.D. dissertation, Stanford 
nomic Sludies $58,1031-42$.

Cooter, R., and M. A. Eisenberg. 1985. "Daniages for Breach of Contract." California Law Review 73. 1432-89.

Edlin, A. S. 1993. "Specific Investments, Holdups, and Efficient Contract Remedies." Chapter 1 of Aspects of the Efficient Recorery of Fixed Costs: $A$ Collection of Essays. Ph.D. dissertation, Stanford University.

Edlin, A.S., and S. Reichelstein. 1993. "Holdups. Standard Breach Remedies, and Optimal lnvestment." Unpublished manuscript.

Fuller, L. and M. A. Eisenberg 1990. Basic Contract Law. West Publishing Co.: St. Paul, Minn.)

Fera v. Village Plaza, Inc. [1976]. 396 Jlich. 639, 242 N.W. 2 d 372.

Freand v. Washinglon Square Press [1974]. 34 X.Y. 2d 379, 357 N.Y.S. 2d 857. 314 N.E. 2 d 419.

Grout, P. 1984. "Investment and Wages in the Absence of Binding Contracts: A Nash Bargaining Approach." Economelrica $52 .+49-60$.

Hermalin, B.. and M. Katz 1993. "Judicial Mlodification of Contracts between Sophisticated Parties: A More Complete liew of Incomplete Contracts and their Breach." Journal of Law, Economics and Organization 9, 230-50.

Konakayama, A., T. Mitsui, and S. Watanabe. 1986, "Eficient Contracting with Reliance and a Damage Measure." Rand Journal of Economics 17. 450-57.

MacLeod, W. B., and J. M. Malcomson. 1993. -Investments, Holdups, and the Form of Market Contracts." American Economic Revieu $83,811-37$.

Milgrom, P. A. and C. Shannon. 1994. "Monotone Comparative Statics." Economeirica 62, 157-180.

Mr. Eddie, Inc, v. Ginsberg, 430 S.W.2d 5 (Tex.Civ.App.1968).

Nordstrom, R. J. and I. F. Woodland. 1950. -Recovery by Building Contractor in Default." Ohio St. Lew Journal $20,193$.

Polinsky, A. M. 1989. An Introduction to Lav and Economics. Boston: Little, Brown.

Rockinghem County r. Luten Bridge Co., 35 F.2d 301 [1929], 4th Cir. Rogerson, W. 1984. EEficient Reliance and Danage Mleasure for Breach of Contract." Rand Journal of
Economics 15, 39-53. Rogerson, W. 1992. "Contractual Solutions to the Holdup Problem." Review of Econoinic Studies 59 ,
F77-794.

Shavell, S. 1980. "Damage Measure for Breach of Contract." Bell Journal of Economics 11, 466-90. Sehwartz, A. 1993. "The Default Rule Paradigm and The Limits of Contract Law," Southern Califormia
Interdisciplinary Lat Journal 3. 389-419.

Shirley MacLaine Parker v. Tuentieth Century Fox [1970] 3 Cal. 3rd, 176, 89 Cal. Rpts. 737. 

Spier, K. E., and M. Whinston. 1994. "Legal Restrictions for Breach of Contract: Strategic Entry,
Reliance, and Renegotiation." Mimeo, Harvard University. Williamson, O. E. 1983. "Credible Commitments: Using Hostages to Support Excliange." American
Economic Review 73,519-40. 
To order any of these papers, see instructions at the end of the list. To subscribe to all NBER Working Papers or the papers in a single area, see instructions inside the back cover. A complete list of NBER Working Papers and Reprints can be accessed on the Internet by using our gopher at nber.harvard.edu.

\begin{tabular}{|c|c|c|c|}
\hline Number & Author(s) & Title & Date \\
\hline 4858 & $\begin{array}{l}\text { James Dow } \\
\text { Gary Gorton }\end{array}$ & $\begin{array}{l}\text { Noise Trading, Delegaled Portfolio } \\
\text { Management, and Economic Welfare }\end{array}$ & $9 / 94$ \\
\hline 4859 & $\begin{array}{l}\text { Francis X. Diebold } \\
\text { David Neumark } \\
\text { Daniel Polsky }\end{array}$ & Job Stability in the United States & $9 / 94$ \\
\hline 4860 & $\begin{array}{l}\text { Michael D. Bordo } \\
\text { Anna J. Schwartz }\end{array}$ & $\begin{array}{l}\text { The Specie Standard as a Contingent Rule: } \\
\text { Some Evidence for Core and Peripheral } \\
\text { Countries, } 1880-1990\end{array}$ & $9 / 94$ \\
\hline 4861 & $\begin{array}{l}\text { David Genesove } \\
\text { Christopher J. Mayer }\end{array}$ & $\begin{array}{l}\text { Equity and Time to Sale in the Real } \\
\text { Estate Market }\end{array}$ & $9 / 94$ \\
\hline 4862 & $\begin{array}{l}\text { Don Fullerton } \\
\text { Diane Lim Rogers }\end{array}$ & Distributional Effects on a Lifetime Basis & $9 / 94$ \\
\hline 4863 & G. William Schwert & Mark-Up Pricing in Mergers and Acquisitions & $9 / 94$ \\
\hline 4864 & $\begin{array}{l}\text { Enrique G. Mendoza } \\
\text { Assaf Razin } \\
\text { Linda L. Tesar }\end{array}$ & $\begin{array}{l}\text { Effective Tax Rates in Macroeconomics: } \\
\text { Cross-Country Estimates of Tax Rates } \\
\text { on Factor Incomes and Consumption }\end{array}$ & $9 / 94$ \\
\hline 4865 & $\begin{array}{l}\text { Jeffrey A. Frankel } \\
\text { Andrew K. Rose }\end{array}$ & $\begin{array}{l}\text { A Survey of Empirical Research } \\
\text { on Nominal Exchange Rates }\end{array}$ & $9 / 94$ \\
\hline 4866 & George J. Borjas & $\begin{array}{l}\text { Assimilation and Changes in Cohor Quality } \\
\text { Revisited: What Happened to Immigrant } \\
\text { Earnings in the 1980s? }\end{array}$ & $9 / 94$ \\
\hline 4867 & $\begin{array}{l}\text { Joel Slemrod } \\
\text { Carl Hansen } \\
\text { Roger Procter }\end{array}$ & $\begin{array}{l}\text { The Seesaw Principle in Intemational } \\
\text { Tax Policy }\end{array}$ & $9 / 94$ \\
\hline 4868 & Louis Kaplow & A Note on Subsidizing Gifts & $9 / 94$ \\
\hline 4869 & $\begin{array}{l}\text { Harry Grubert } \\
\text { Joel Slemrod }\end{array}$ & $\begin{array}{l}\text { The Effect of Taxes on Investment and } \\
\text { Income Shifting to Puerto Rico }\end{array}$ & $9 / 94$ \\
\hline 4870 & Dani Rodrik & $\begin{array}{l}\text { What Does the Political Economy Literature } \\
\text { on Trade Policy (Not) Tell Us That We } \\
\text { Ought to Know? }\end{array}$ & $9 / 94$ \\
\hline 4871 & Lars E. O. Svensson & $\begin{array}{l}\text { Estimating and Interpreting Forward } \\
\text { Interest Rates: Sweden 1992-1994 }\end{array}$ & $9 / 94$ \\
\hline 4872 & George J. Borjas & Immigration and Welfare, 1970-1990 & $9 / 94$ \\
\hline
\end{tabular}


To order any of these papers, see instructions at the end of the list. To subseribe to all NBER Working Papers or the papers in a single area, see Instructions Inside the back cover. A complete list of NBER Working Papers and Reprints can be accessed on the Internet by using our gopher at nber.harvard.edu.

$4873 \quad$ Jose De Gregorio Federico Sturzenegger

Title

Date

Brandice J. Canes Harvey S. Rosen

Raghuran G. Rajan Luigi Zingales

Gene Grossman Elhanan Helpman

Gene Grossman Elhanan Helpman

C. Keith Head John C. Ries

Deborah L. Swenson

David M. Cutler

$4880 \quad$ Douglas Holtz-Eakin John R. Penrod

Harvey S. Rosen

$4881 \quad$ Nouriel Roubini Gian Maris Milesi-Ferretti

$4882 \quad$ Nouriel Roubini Gian Maria Milesi-Ferrelti

Raquel Fernandez Richard Rogerson

R. Glenn Hubbard Jonathan Skinner Stephen P. Zeldes

Fiscal Policies, Capital Formation and Capitalism

Oliver Hart John Moore

Debt and Seniority: An Analysis of the Role of Hand Claims in Constraining Management

$10 / 94$

Explaining Investment Dynamics in U.S. 
To order any of these papers, see instructions at the end of the list. To sobscribe to all NBER Working Papers or the papers in a single area, see instructions inside the back cover. A complete list of NBER Working Papers and Reprints can be accessed on the Internet by using our gopher at nber.harvard.edu.

\begin{tabular}{|c|c|}
\hline Number & Author(s) \\
\hline 4888 & $\begin{array}{l}\text { Martin Feldstein } \\
\text { James H Stock }\end{array}$ \\
\hline 4889 & $\begin{array}{l}\text { Mark Hooker } \\
\text { Michael Knetter }\end{array}$ \\
\hline 4890 & $\begin{array}{l}\text { John R. Graham } \\
\text { Campbell R. Harvey }\end{array}$ \\
\hline 4891 & W. Kip Viscusi \\
\hline 4892 & Alan M. Taylor \\
\hline 4893 & $\begin{array}{l}\text { Maurice Obstfeld } \\
\text { Kenneth Rogoff }\end{array}$ \\
\hline 4894 & Michael M. Knetter \\
\hline 4895 & Peter Diamond \\
\hline 4896 & Lawrence H. Goulder \\
\hline 4897 & $\begin{array}{l}\text { A. Lans Bovenberg } \\
\text { Lawrence H. Goulder }\end{array}$ \\
\hline 4898 & $\begin{array}{l}\text { Barry Eichengreen } \\
\text { Andrew K. Rose } \\
\text { Charles Wyplosz }\end{array}$ \\
\hline 4899 & Shane Greenstein \\
\hline 4900 & $\begin{array}{l}\text { Orazio P. Attanasio } \\
\text { Thomas C. DeLeire }\end{array}$ \\
\hline 4901 & $\begin{array}{l}\text { Timothy F. Bresnahar' } \\
\text { Shane Greenstein }\end{array}$ \\
\hline 4902 & Joel Slemrod \\
\hline 4903 & $\begin{array}{l}\text { Assaf Razin } \\
\text { Efraim Sadka }\end{array}$ \\
\hline
\end{tabular}

Title

Measuring Money Growth When Financial Markets Are Changing

Unemployment Effects of Military Spending: Evidence from a Panel of States

Market Timing Ability and Volatility Implied in Investment Newsletters' Asset Allocation Recommendations

Cigarelte Taxation and the Social Consequences of Smoking

Domestic Saving and Intemational Capital Flows Reconsidered

The Intertemporal Approach to the Current Account

Why Are Retail Prices in Japan So High?: Evidence from German Export Prices

Insulation of Pensions from Political Risk

Environmental Taxation and the "Double Dividend": A Reader's Guide

Optimal Environmental Taxation in the Presence of Other Taxes: General Equilibrium Analyses

Speculative Attacks on Pegged Exchange Rates: An Empirical Exploration with Special Reference to the European Monetary System

From Superminis to Supercomputers: Estimating Surplus in the Computing Market

IRAs and Household Saving Revisited:

Some New Evidence

The Competitive Crash in Large-Scale

Commercial Computing

Free Trade Taxation and Protectionist Taxation

Resisting Migration: The Problems of Wage

Rigidity and the Social Burden
$10 / 94$

10,94

Date

$10 / 94$

$10 / 94$

$10 / 94$

$10 / 94$

$10 / 94$

$10 / 94$

$10 / 94$

$10 / 94$

10,94

$10 / 94$

10,94

$10 / 94$

$10 / 94$

$10 / 94$ 
To order any of these papers, see instructions at the end of the list. To subscribe to all NBER Working Papers or the papers in a single area, see instructions inside the back cover. A complete list of NBER Working Papers and Reprints can be accessed on the Internet by using our gopher at nber.harvard.edu.

\begin{tabular}{|c|c|c|c|}
\hline Number & Aulhor(s) & Tille & Date \\
\hline 4904 & $\begin{array}{l}\text { Ernst R. Berndt } \\
\text { Linda Bui } \\
\text { David Reiley } \\
\text { Glen Urban }\end{array}$ & $\begin{array}{l}\text { The Roles of Marketing, Product Quality and } \\
\text { Price Competition in the Growth and } \\
\text { Composition of the U.S. Anti-Ulcer } \\
\text { Drug Industry }\end{array}$ & $10 / 94$ \\
\hline 4905 & $\begin{array}{l}\text { Thomas C. Kinnaman } \\
\text { Don Fullerton }\end{array}$ & $\begin{array}{l}\text { How a Fee Per-Unil Garbage Affects } \\
\text { Aggregate Recycling in a Model with } \\
\text { Heterogeneous Households }\end{array}$ & $10 / 94$ \\
\hline 4906 & Daniel S. Hamermesh & $\begin{array}{l}\text { Aging and Productivity, Rationality and } \\
\text { Matching: Evidence from Economists }\end{array}$ & $1 0 \longdiv { 9 4 }$ \\
\hline 4907 & $\begin{array}{l}\text { Kooyul Jung } \\
\text { Yong-Cheol Kim } \\
\text { René M. Stulz }\end{array}$ & $\begin{array}{l}\text { Investment Opportunities, Managerial } \\
\text { Discretion, and the Security Issue } \\
\text { Decision }\end{array}$ & $10 / 94$ \\
\hline 4908 & $\begin{array}{l}\text { Jun-Koo Kang } \\
\text { René M. Stulz }\end{array}$ & $\begin{array}{l}\text { How Different is Japanese Corparate } \\
\text { Finance? An Investigation of the } \\
\text { Information Content of New Security Issues }\end{array}$ & $10 / 94$ \\
\hline 4909 & Robert J. Barro & Democracy and Growth & $10 / 94$ \\
\hline 4910 & Richard B. Freeman & Crime and the Job Market & $10 / 94$ \\
\hline 4911 & Rebecca M. Blank & The Dynamics of Part-Time Work & $11 / 94$ \\
\hline 4912 & George J. Borjas & $\begin{array}{l}\text { Ethnicity, Neighborhoods, and Human Capital } \\
\text { Extemalities }\end{array}$ & $11 / 94$ \\
\hline 4913 & $\begin{array}{l}\text { George J. Borjas } \\
\text { Bernt Bratsberg }\end{array}$ & $\begin{array}{l}\text { Who Leaves? The Outmigration of the } \\
\text { Foreign-Bom }\end{array}$ & $11 / 94$ \\
\hline 4914 & Christopher J. Ruhm & Economic Conditions and Aloohol Problems & $11 / 94$ \\
\hline 4915 & Aaron S. Edlin & $\begin{array}{l}\text { Cadillac Contracts and Up-Front Payments: } \\
\text { Efficient Investment Under Expectation } \\
\text { Damages }\end{array}$ & $11 / 94$ \\
\hline
\end{tabular}

Copies of the above working papers can be obtained by sending $\$ 5.00$ per copy (plus $\$ 10.00$ per arder for postage and handling for all locations outside the continental U.S.) to Working Papers, NBER, 1050 Massachuselts Avenue, Cambridge, MA 02138-5398. Advance payment is required on all orders. Payment may be made by check or credit card. Checks should be made payable to the NBER and must be in dollars drawn on a U.S. bank. If paying by credit card, include the cardholder's name, account number and expiration date. For all mail orders, please be sure to include your return address and telephone number. Working papers may also be ordered by telephone $(617-868-3900)$, or by fax $(617-868-2742)$. 


\section{National Bureau of Economic Research}

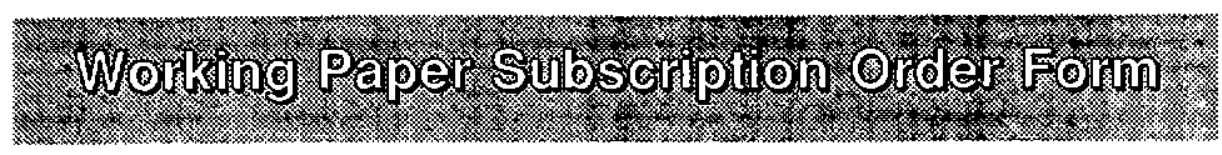

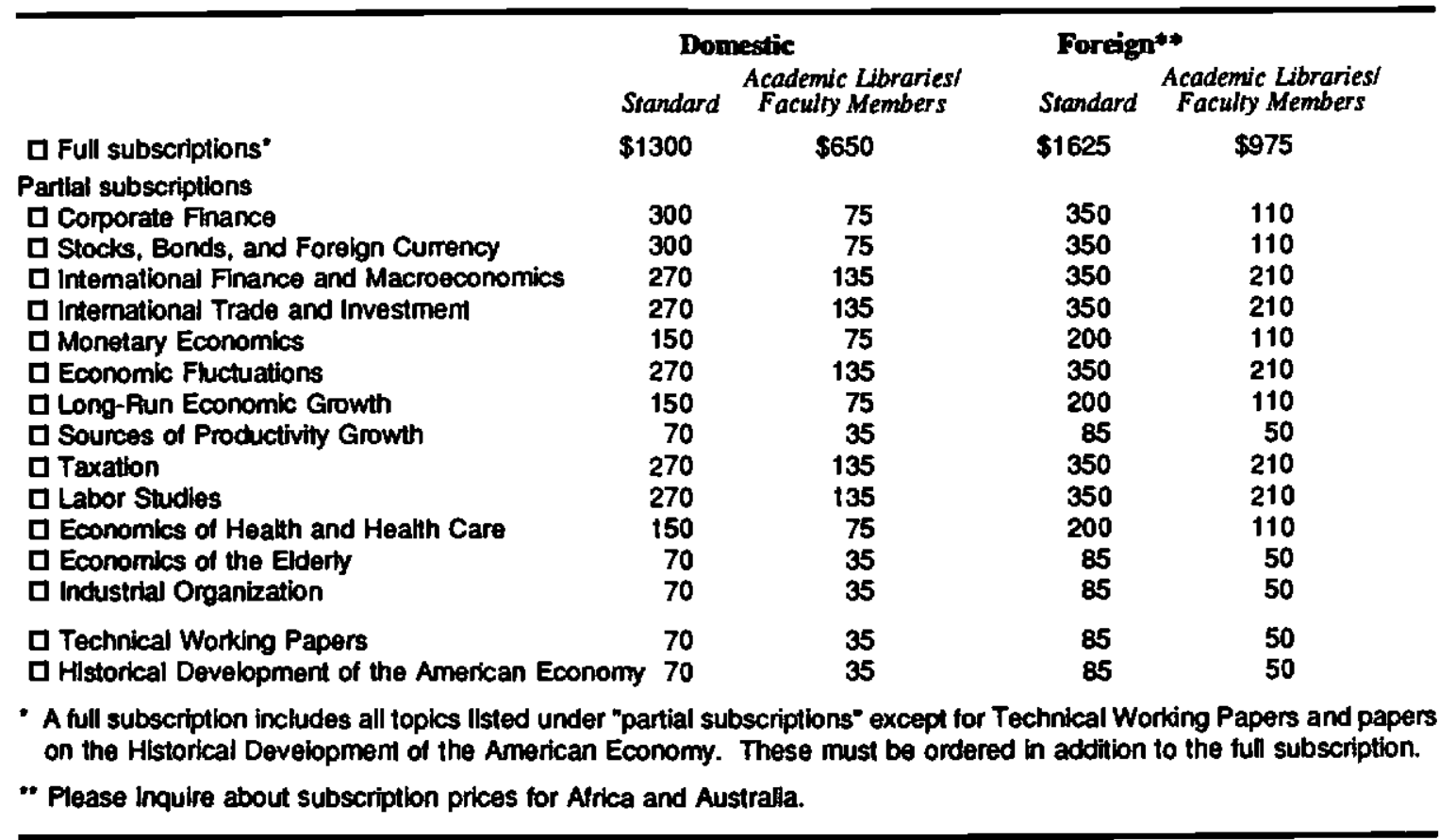

\section{PAYMENT OPTIONS}

YES! Please begin my subscription to the NBER Working Paper Series. I have indicated above which papers I would like so recelve.

By Phone: (617) 868-3900

By FAX: (617) 868-2742

By Mail: Publications Department

National Bureau of Economic Research 1050 Massachusetts Ave.

D Payment in the amount of enclosed.

$\square$ Please charge my: $\square$ VISA $\square$ MasterCard

Card Number:

Card expiration:

Signature:
Please mail my papers to this address:

Name

Address

Phone:

FAX: 